\title{
TERRITÓRIOS MÓVEIS DE UMA ESCRITA FEMININA EM CONSTRUÇÃO: PERSPECTIVA CONTEMPORÂNEA DE EXİLIO E LITERATURAS MIGRANTES
}

\author{
WRITINGO OF WOMEN IN LATIN AMERICA: FROM THE \\ CONSTRUCTION OF PROTAGONISTS TO THE PROTAGONISM \\ IN WRITING
}

\author{
Marta Francisco de Oliveira' \\ [https://orcid.org/0000-0002-5212-5361] \\ DOI: 10.30612/raido.v14i35.11866
}

RESUMO: O artigo tem por objetivo propor uma reflexăo acerca de como a escrita feminina no Brasil se constrói sobre um território móvel e produtivo, abrindo espaço para novas perspectivas apontadas pelos estudos contemporâneos. Escritoras e pesquisadoras desempenham um papel como intelectuais que extrapola os domínios da arte e da cultura e se inscrevem como opçăo política e de resistência. Deste modo, através de uma breve referência a uma história de literatura de escrita de mulheres, nacional e regional, revista pela pesquisa de Araújo (2006), Duarte (2018) e Pellegrini e Sena (2014), propomos a ampliaçâo dos estudos e das leituras para, em seguida, incentivar a reflexăo sobre como o exílio e os movimentos migratórios se inscrevem na perspectiva contemporânea da escrita feminina. É neste sentido que se instaura também o pensamento de(s)colonial, inaugurando uma nova episteme, ou pelo menos um novo posicionamento frente à (ou ao lado da) epistemologia retórica da modernidade, nas palavras de Mignolo (2019), o que exige uma postura intelectual que responda, satisfatoriamente, às novas formas de apresentaçăo dos discursos e narrativas pautados no entendimento das literaturas das minorias, de 'fronteira', na intersecçâo com a autoria feminina

Palavras-chave: autoria feminina; exílio; literaturas migrantes; pensamento de(s)colonial.

ABSTRACT: The article aims to propose a reflection on how female writing in Brazil is built on a mobile and productive territory, opening space for new perspectives pointed out by contemporary studies. Writers and researchers play a role as intellectuals that go beyond the domains of art and culture and sign up as a political and resistance option. Thus, through a brief reference to a history of women's writing literature, national and regional, reviewed by Araújo (2006), Duarte (2018) and Pellegrini and Sena (2014), we propose the expansion of studies and readings to then encourage reflection on how exile and migratory movements are inscribed in the contemporary perspective of female writing. It is in this sense that the thought of colonial (s) is also

1 Professora da Universidade Federal de Mato Grosso do Sul - PNPD - PPGEL- FAALC/CPCX. 
established, inaugurating a new episteme, or at least a new positioning in front of (or alongside) the rhetorical epistemology of modernity, in the words of Mignolo (2019), which requires an intellectual posture that responds, satisfactorily, to the new forms of presentation of speeches and narratives based on the understanding of minority literature, of 'frontier', at the intersection with female authorship.

Keywords: Brazilian popular music; censorship; phonographic industry; Lira Paulistana; Itamar Assumpçăo. Female authorship; exile; migrant literature; decolonial thinking.

\section{CONSIDERAÇÕES INICIAIS}

Brincar de pensar A arte de pensar sem riscos. Náo fossem os caminhos de emoçâo a que leva o pensamento, pensar já teria sido catalogado como um dos modos de se divertir. Năo se convidam amigos para o jogo por causa da cerimônia que se tem em pensar. O melhor modo é convidar apenas para uma visita, e, como quem nāo quer nada, pensa-se junto, no disfarçado das palavras. (LISPECTOR, 1999, p. 23)

Parece ser desnecessário afirmar que, conforme a chamada para este dossiê, em nossa história literária, tanto brasileira como de toda a América Latina, a presença feminina nos textos se destacava como personagens - inclusive com grande potência representativa, com significados simbólicos que permanecem até hoje em nosso imaginário literário, cultural e popular - mas que ainda precisamos resgatar e fazer jus à autoria de mulheres. De fato, considerar que a escrita de mulheres esteve ausente da lista de obras representativas - exiladas desse contexto por diversas razóes - náo significa atestar que nâo exista, pois um olhar histórico mais atento revela o contrário do que quer (ou queria) nossa historiografia ${ }^{2}$ mais tradicional, e a desmente em termos de abundância de autoras e textos escritos (ARAÚJO, 2006). Trata-se, mais precisamente, de perceber certa possibilidade de compreensăo da condiçáo de exílio e deslocamento, grosso modo, pois os espaços validados de escrita e reconhecimento năo pertenciam a todos: era território simbólico do qual mulheres escritoras eram retiradas e/ou proibidas de entrar, alheio a elas. A via de acesso a tal espaço, para desenvolver a arte de escrever sem riscos, precisava ser meio disfarçada, como um convite amavelmente estendido por aqueles de direito, e aceito pelas escritoras como que para um jogo, uma mera visita como garantia de náo permanência.

É neste respeito que se constrói a ideia de que a escrita de autoria feminina transita por territórios móveis, incertos, literal e simbolicamente, construindo um percurso desde sua figuraçâo e representatividade no texto, como constituiçâo de personagens, para por fim chegar ao reconhecido protagonismo na escrita. De fato, sequer hoje podemos afirmar que se trata de um território conquistado; antes, a conquista está em processo, aliada a novas concepçóes teóricas que repensam os lugares de produçấo e (re)validam a atividade criadora de mulheres.

2 Refiro-me aqui à historiografia enquanto ideia de registro e descriçấo de autores, obras, contextos históricos, sociais e culturais convencionados, segundo certas intençōes, dos períodos literários apresentados em obras voltadas para o público leitor interessado em literatura, de acordo com critérios de seleçáo daqueles considerados relevantes e dignos de entrar para uma tradiçáo dita canônica. Neste caso, toda seleçấo implica exclusăo de itens nâo pertinentes aos interesses dos grupos que fazem tal escolha. 
Historicamente, manter os nomes de mulheres escritoras longe das listas de autoria literária se devia mais a questôes de ordem da tentativa de apagamento e invisibilizaçăo dessas escritoras, mantendo-as como que exiladas em um território móvel, inseguro e instável, do que à inexistência de autoras e obras. Năo cabia às mulheres adentrar a cena pública e tampouco espaços marcadamente masculinos, como era o da escrita, e ter relevância neste território simbólico. Porém, na atualidade é possível rastrear a quantidade de autoras atuantes no século XIX no Brasil, por exemplo, e descobrir que seu número abundante nâo condiz com uma tradiçáo que preservou quase exclusivamente nomes de escritores homens como pilares de nossa literatura nacional, replicados e consagrados por uma academia que determina manuais e currículos escolares indicando nomes e títulos representativos da periodizaçâo literária repassada a estudantes do ensino médio e universitários (DUARTE, 2018).

Se, paulatinamente, nomes de escritoras começam a ser agregados ao rol de escritores e autores, mesmo aquelas que conseguiram se consagrar, de certa forma, sofreram com o estigma de se dedicar a uma literatura feminina, sentimental, voltada para temas domésticos que, em princípio, interessariam apenas a mulheres, limitando (e menosprezando) seu público. Desse modo, nada mais interessaria em um texto escrito por mulheres, quer estilo quer capacidade reflexiva ou crítica, pois náo mereceria a atençâo de um público mais exigente, o masculino. No século XIX, o público leitor feminino começa a ser visado por periódicos, os quais estavam cheios de páginas de moda, de receitas, ou de contos com ensinamentos morais, entre outros ${ }^{3}$. Mas, ao lado dessa figura da leitora, visada como público consumidor, também surge a figura da mulher escritora. Uma realidade perpetuada ao longo do tempo, portanto, foi muito bem explanada pela escritora Virginia Woolf: "durante muito tempo na história, 'anônimo' era uma mulher". Ou seja, mesmo que escrevesse, mais valia ocultar a autoria e refugiar-se em uma 'androginizaçăo', adotando um nome masculino, para se autorizar a adentrar o mundo literário no qual a escrita se tornava uma profissăo (LANSER, 2014; FIGUEIREDO, 2013). 'Um teto todo seu', para a criaçăo escrita de mulheres, é algo a ser convertido em constante busca, embora a contemporaneidade aparentemente tenha aplainado o caminho.

Sem dúvida, a partir do século seguinte muitas alteraçôes foram sendo notadas no cenário da escrita no Brasil. Entretanto, muito do estigma ainda permaneceria, bem entrado o século XX. Mesmo Clarice Lispector, apesar de seu reconhecimento como romancista, contribuiu com jornais brasileiros em colunas e páginas femininas entre as décadas de 1950 e 1960, dando receitinhas caseiras e comentando amenidades que, esperava-se, deveriam agradar um público menos exigente (LISPECTOR, NUNES, 2018). Vale a ressalva de que, por se tratar de Clarice Lispector, mesmo sob o pseudônimo de Helen Palmer, muito do que se publicava na coluna ia sutilmente além do tom ameno da conversa entre vizinhas, 'mulherzinhas' perfeitamente enquadradas em seu papel social. Ainda assim, o que prevalecia nesses textos era a superficialidade e utilidade doméstica da escrita, persistente inclusive em leituras mais contemporâneas: em 2013, um quadro do Fantástico, programa das noites de domingo da Rede Globo de televisăo, exibia tais textos claricianos em linguagem atualizada, próxima dos espectadores

3 No Jornal das Famílias, mesmo Machado de Assis publicou textos voltados para este público feminino leitor (CRESTANI, 2009). 
esperados para o dia e horário, encenados por uma atriz como se fosse um capítulo curtíssimo de uma dramatizaçáo. Apesar do mérito de incluir textos de Lispector na televisăo aberta, o quadro era bonitinho para assistir, mas sem profundidade.

Se ainda percebemos a resistência quanto à escrita feminina, à escrita feita por mulheres, uma voz contrária tem se elevado há algum tempo no Brasil e na América Latina. "A crítica feminista trouxe novas abordagens a estas obras, recuperou escritoras e obras esquecidas e demarcou o espaço de luta e de discussóes importantes na literatura de autoria de mulheres", informa-nos a chamada para este número temático, propondo uma postura política de instauraçâo de uma voz e de um espaço, na esteira de outros projetos que repensam as autorias, as escritas e as vozes como meios essenciais de resistência, de (re)invençấo, de superaçăo e desvencilhamento dos estigmas, reduçôes e aprisionamentos aos quais autoras e escritoras mulheres foram submetidas ao longo do tempo. A esfera literária, em foco, promove o pensar do protagonismo feminino na escrita năo como brincadeira, passatempo, como poderia sugerir a epígrafe escolhida. Por meio da literatura, o pensamento ganha a forma de risco, de arriscar-se, de aproximaçăo a debates políticos, culturais, sociais, intelectuais, o convidativo jogo que, superando a inibiçâo de fingir 'nâo querer nada', deixa de ser mera visitinha de amigos e propóe, sem medo, o pensar juntos na palavra mal disfarçada, ou já sem disfarce algum.

\section{UMA HISTÓRIA DE ESCRITA DE MULHERES CONTADA EM LIVROS NAS PERSPECTIVAS NACIONAL E LOCAL?}

Ampliando a reflexâo contemporânea acerca da escrita de autoria feminina através de uma revisăo histórica e bibliográfica, esta se desenha como um esforço de conquista e de reconquista de um espaço, um território móvel em construçăo. Sem dúvida, a repetiçâo é necessária, pois implica a persistência da negaçăo e a constante interposiçăo de dificuldades para o estabelecimento do estatuto da escrita de autoria de mulheres no espaço privilegiado da literatura reconhecida, ampliando a lista de nomes no cânone, por um lado, e o expandindo em múltiplas direçōes, por outro, enquanto mais formas de produçâo textual literária foram sendo inscritas no rol da literatura, para além de um cânone consagrado por certas instituiçôes e pela academia. É um esforço político instaurado como resistência. No entanto, é muitas vezes esquecido ou deixado de lado, talvez por certa naturalizaçâo dos processos de reconhecimento, talvez pela permanência do ranço da condescendência social de atribuir um valor estético limitado a obras de produtoras mulheres.

A observaçâo do contemporâneo, na cena social, política e cultural, ainda apresenta uma visâo parcial e determinada por critérios que, ao longo dos anos, restringem a importância da produçăo intelectual feminina, quando năo a menosprezam direta e implacavelmente. Berenice Bento, em artigo publicado em 22 de abril de 2020, na Revista Cult, faz uma análise do modo como figuras femininas săo apresentadas em memes relacionados a questôes políticas no Brasil contemporâneo. Quero me apropriar de suas consideraçóes e fazê-las migrar para o espaço da escrita. O ideário construído socialmente ao longo do tempo faz a vinculaçăo quase imediata ou direta entre o feminino e atributos pouco valorizados, visando reduzir a relevância das produçóes de mulheres. Se, por um lado, Bento destaca que atributos como a loucura, a instabilidade, 
corpos descontrolados, certa dose de infantilidade, a ausência de racionalidade e pouca autoridade săo amplamente relacionados com o feminino nos memes políticos, mesmo quando se referem à figura masculina de maior poder no país, por outro podemos usar essa referência na literatura como espaço simbólico que mimetiza as relaçōes sociais.

Na esteira desta percepçăo, a construçâo social de metáforas e imagens fortemente marcadas pelo feminino incentiva o riso e o deboche, porém a crítica é rasa, permanece na superfície do ideário assumidamente androcêntrico, que de modo natural valoriza o que faz referências ao masculino ao passo que promove a interpretaçáo cômica e caricata dos fatos por meio da aproximaçăo a atributos negativos ligados ao feminino. Tal forma de compreensâo é tâo difundida que permeia muitos discursos veiculados socialmente, para além da esfera política, e revela a violência e o menosprezo explícita ou veladamente dirigidos às mulheres. Nâo surpreende, portanto, que haja tantos entraves para a natural ascensâo, visibilidade e valorizaçâo das produçôes de autoria feminina, preservando adequadamente a memória cultural ao longo do tempo.

Assim, vale a pena uma rápida pesquisa para, aos poucos, reinserir dados, fatos e nomes a essa história para que esteja cada vez mais presente nos espaços de divulgaçâo e que se promova a observaçăo e percepçăo da construçáo da literatura de autoria de mulheres no Brasil. Tal construçáo se converte em território móvel e instável, mutável, em uma espécie de migraçăo ao passo que nomes săo recuperados e obras surgem ou ressurgem. E, vale o destaque, sâo outras mulheres, em sua maioria, as que buscam promover essa recuperaçăo e valorizaçăo, como pesquisadores, estudantes e críticas. Neste sentido, o espaço mais propício, talvez, ainda seja o ambiente universitário, para formaçáo acadêmica relacionada às artes, linguagem, literatura, e posteriormente o escolar, como continuidade e local de trabalho desses profissionais formados, mulheres e homens. No entanto, outros locais, sobretudo os marcadamente culturais, precisam também ampliar essa divulgaçáo e atrair um público maior e mais variado. Cidades maiores, e capitais, podem se sobressair neste aspecto.

Em Săo Paulo, por exemplo, entre abril e maio de 2019, a Biblioteca Mario de Andrade foi o local da Exposiçăo: Pioneiras. No site oficial da prefeitura de Săo Paulo4, a chamada tinha o título expandido para "Autoras mulheres no acervo de raridades - Cinquenta livros escritos por autoras brasileiras entre 1754 e 1933". O texto acompanhante apresenta os curadores e a seleçâo de poemas, romances, ensaios e biografias. Entre outras, destacam-se as autoras Teresa Orta, paulista, e "poemas da 'musa' e heroína da Inconfidência Mineira Bárbara Heliodora, lançados postumamente em 1862". O texto prossegue: "a cronologia passa por Nísia Floresta, nossa primeira autora feminista, Julia Lopes de Almeida, que publicou cerca de 40 livros no século XIX, Gilka Machado,(...) e encerra com Parque Industrial, romance de estreia de Pagu, de 1933, que na época assinava Mara Lobo". Sáo iniciativas assim que năo podem mais se restringir a um público específico, ou permanecer circunscritas a um círculo pequeno de produtores culturais, seus apoiadores e apreciadores. Tal público pode e deve ser ampliado, via classe docente em geral, e inclusive via cursos de graduaçâo e pós-graduaçâo, para intensificar a formaçăo e a sensibilizaçăo para eventos deste tipo, suas diversas formas de divulgaçâo e participaçâo.

4 https://www.prefeitura.sp.gov.br/cidade/secretarias/cultura/bma/programacao/index.php?p=25515, acesso em 21/04/2020. 
É válido destacar, neste aspecto, o esforço de mulheres dedicadas à escrita em suas variadas formas, no empenho de divulgar tais iniciativas e incentivar a ampliaçáo do público participante e do conhecimento das autoras e obras. Cito, por exemplo, Carla Batista, na coluna Mulheres em Movimento, na FolhaPE.com.br, quem escreveu, em 01/05/2019, sob o título "Autoras mulheres pioneiras", um texto sobre a "importância de espaços que se abrem para fazer conhecer e ouvir as palavras/vozes das mulheres". Assim, fez a divulgaçāo, em espaço geograficamente longe dos grandes centros no sudeste, sobre a exposiçáo na Biblioteca Mario de Andrade, e o texto permanece para consulta on-line e como forma de acesso parcial ao conteúdo do evento.

A citaçáo é longa, mas parece interessante para demonstrar como é preciso falar abertamente sobre toda a herança que estas mulheres construíram e nos legaram, ao passo que demonstra que todos os espaços, mesmos os que poderiam ser considerados periféricos e distantes, podem ser divulgadores dos textos e das autoras, abarcando todo o território nacional. Ademais, o trabalho da colunista também merece destaque, como divulgadora e como produtora de textos. O jornal, impresso ou em ambiente virtual, pode ampliar a divulgaçăo entre os mais variados públicos. Assim, informa a colunista:

Adalzira Bittencourt (1904-1976) publicou várias obras sobre a participaçáo política e social das mulheres. No livro "Sua Excia. A Presidenta da República", um romance futurista baseado nos ideais do Partido Republicano Feminino, vislumbrava a eleiçấo da $1^{\text {a }}$ presidenta no ano de 2.500. Nísia Floresta, considerada a primeira escritora feminista do Brasil, era também atenta às questôes ambientais e dos povos indígenas. Publicou "Direitos das Mulheres e Injustiças dos Homens", obra inicial, em 1832. Estes dois livros estăo entre os 51 em exposiçăo na Biblioteca Mário de Andrade, no centro de Sáo Paulo. Os exemplares integram a seçáo de obras raras da Biblioteca, que tem mais de 40 mil volumes. $O$ documento mais antigo data de 1.477. A pesquisadora e bibliotecária Joana D’arc de Andrade e Rízio Santana, especialistas em obras raras, săo os responsáveis pelo acervo e localizaram cerca de 120 livros de mulheres entre as raridades. A organizaçăo da exposiçăo, da qual săo curadores, foi proposta pela nova diretora da Biblioteca, Josélia Aguiar. Joana, quando se referiu a Auta de Souza, natalense nascida no século XVIII, contou que mulher publicar năo era bem visto. "Os escritores năo gostavam nem ao menos de prefaciá-las". Imaginem a ousadia: uma mulher expor ideias publicamente! Bárbara Heliodora, cujo companheiro era o inconfidente mineiro Alvarenga Peixoto, teve poemas publicados junto aos dele, o que hoje dificulta identificar o que é de autoria dela. Rita Joana Souza, citada no livro "Mulheres escritoras do século XIX", era pernambucana e morreu aos 22 anos. Chegou a escrever tratados de filosofia. Mas nada foi encontrado dos seus escritos. Houve até uma mulher que foi convidada para certa academia de letras. Năo podendo aceitar em razăo do seu sexo, pasmem! foi o marido quem assumiu no seu lugar.

Confinar mulheres ao espaço doméstico tem significados e repercussôes que săo muito mais profundos e restritivos do que o enclausuramento em si. Até a expressáo dos sentimentos e pensamentos era cerceada, ocultada. Engolidos. Sáo várias as estratégias utilizadas para apagar existências.

A exposiçăo finaliza com “Revoluçăo Industrial. Romance Proletário", da modernista Patrícia Galvăo, a Pagu. O exemplar é único sobrevivente, segundo a bibliotecária. Após 26 de maio, quando termina a mostra, os livros estarăo disponíveis para consulta. Eles fazem parte da coleçấo geral da Mário de Andrade, que tem mais de 
300 mil volumes. Com mostras como estas "a ideia é valorizar encontros literários", afirma Joana. A Biblioteca espera com a exposiçâo valorizar a produção das mulheres, muitas delas feministas, em grande parte desconhecida. Entre as novidades, para mim, uma pernambucana que se radicou em Sáo Paulo, a feminista Josefina Azevedo e sua publicaçâo de 1987 (sic), "Galeria Ilustre (Mulheres Célebres)", que inclui entre outras a biografia de George Sand. [...]

Termino com palavras da Conceiçăo Evaristo, "Já passou da hora de reescrever a história da literatura brasileira, da intelectualidade brasileira, afirmando nomes que ficaram fora"... (BATISTA, 2019)

Textos como este de Carla Batista são reveladores. Embora as dimensóes de tempo e espaço tenham sido ampliadas na atualidade do mundo virtual, os locais fixos e as vias de acesso se tornam móveis. Vivendo no Mato Grosso do Sul, posso saber o que ocorre na cena cultural dos grandes centros como Sáo Paulo ou Rio de Janeiro, ou ter a possibilidade de ver e participar de exposiçōes e eventos literários sem precisar viajar, e ler jornais e outros veículos de comunicaçăo de outros estados brasileiros e do mundo, sem importar a data de sua realizaçăo, desde que se possa fazer o acompanhamento ou resgate do que já esteve no cenário cultural. É um ambiente que se torna cada vez mais móvel, migrante, e os textos também seguem esse padrăo. $\mathrm{O}$ que Batista escreveu pode incentivar um leitor a buscar o site oficial da biblioteca, ou a procurar mais informaçōes sobre as autoras e obras citadas, possibilitando uma migraçăo, enquanto movimento, de leitores, de leituras, de intelectuais, de textos, da literatura.

Deste modo, cabe às pesquisadoras, professoras, escritoras e autoras contemporâneas em geral - além dos profissionais homens, sem dúvida - propagar, divulgar e incentivar a leitura e o estudo de textos de autoria feminina. Retomar nossa própria história de produçăo e publicaçâo de textos literários revela a necessidade de voltar o olhar para essa construçâo ao longo do tempo e promover a reescrita desta memória. É também neste sentido que se desenha uma outra possível concepçăo de literatura migrante, de autoras e obras que 'migram' do espaço da invisibilizaçáo para a cena literária contemporânea, para o território de sua (re)descoberta, de sua (re)conquista de um espaço mais privilegiado de inserçăo, estudo e divulgaçăo.

Portanto, alguns trabalhos de escritoras mulheres poderiam e deveriam compor, de modo mais definitivo e valorizado, as listas de referência obrigatória para qualquer estudo de nossa literatura brasileira. Na busca por trabalhos voltados para esta tarefa tâo relevante para repensar a escrita de mulheres, alguns títulos precisam deixar o anonimato e receber maior atençâo. O interessante trabalho de Maria da Conceiçăo Pinheiro Araújo (2006), por exemplo, faz uma revisâo necessária dessa história literária marcadamente feminina que se recusa a ser apagada. No artigo, cujo título é 'Lilithes, do século XX, abrem a caixa de Pandora das Sherazades, do século XIX', a pesquisadora apresenta uma lista de obras para valorizar o que foi feito ao longo do tempo em prol da memória da escrita feita por mulheres. Sáo citadas autoras, escritoras e pesquisadoras e suas obras, desde o século XIX até a década de 1970, no século XX, para entăo dar atençăo especial ao recorte dos anos de 1990.

Em cada título citado, percebe-se que o esforço de compilar textos de autoria feminina, preservá-los e divulgá-los fora um empenho conjunto de mulheres, intelectuais de suas épocas, para dar visibilidade ao que poderia ser facilmente ignorado, como se 
os atributos de 'notáveis', 'ilustres', 'intelectuais', năo pudessem ser associados a mulheres. Num trabalho de persistência, resistência e memória, leitoras e leitores podem se surpreender ao descobrir que o primeiro título citado data de 1897, de Josefina Álvares de Azevedo, e que, no período dos 20 anos seguintes, outros dois surgiram, em 1899, de Inês Sabino, e outro em 1907, já no século XX, de Andradina de Oliveira. Os dois primeiros tratavam de 'mulheres ilustres', utilizando o adjetivo no título, e o último se concentrava em mulheres na regiâo do Rio Grande do Sul, com destaque para as escritoras. A lista segue com Cândida de Brito, Adalgisa Bittencourt e Alzira Freitas Tacques, com obras em 1929, 1948 e no período entre 1956 e 1958, cujos títulos abarcam antologia, escritoras e poetisas e seus textos. Graças a mulheres pesquisadoras como Araújo (2006), portanto, muito pode ser redescoberto sobre a inserçáo feminina na literatura nacional ao longo do tempo, inspirando pesquisas de cunho mais regional também, recuperando a memória local de escritoras, intelectuais, autoras, promovendo uma necessária revisăo da produçăo literária no Brasil, para que entăo possamos (re)traçar o panorama contemporâneo de nossa literatura, sem os espaços vazios do apagamento e da invisibilização voluntários contra o feminino.

Neste contexto, pensar na produçâo literária escrita por mulheres em Mato Grosso do Sul inclui observar como o fazer literário tem sofrido alteraçôes e influências dos processos migratórios, exílicos e diaspóricos, tanto geográfico e físico como virtual e simbólico. Habitar uma regiăo fronteiriça é também se colocar, figurativamente, nos interstícios culturais, linguísticos, artísticos e estéticos que incidem na produçâo escrita. No entanto, a construçâo de uma memória literária regional também é permeada por uma história năo muito favorável à preservação e incentivo da escrita de mulheres. De fato, esta é uma memória a ser (re)buscada e (re)desenhada à procura de nomes a inserir e dar visibilidade, apesar dos esforços que já tem sido feitos. Resta, no entanto, muito a ser feito, a ponto de incentivar a divulgaçăo mais ampla de obras de escritoras locais.

Destaco, por exemplo, a obra Vozes da literatura, publicada em 2014 pela Fundaçăo de Cultura do estado de MS, cujos objetivos săo expressos logo no início da obra, segundo lemos:

[...] nossas paragens săo retratadas há séculos por cronistas e desenhistas - viajantes da época. (...) A escrita, legítimo e seguro modo de salvaguarda da cultura e história da sociedade, se mantém como a mais adequada forma de registro de um povo. (...) $\mathrm{Na}$ convicçâo de que educaçâo e cultura sâo as principais balizas que estruturam a singularidade de nosso povo, fomentamos a formaçáo de novos leitores e a difusăo de nossa literatura, que, além de nomes já consagrados, se fortalece com a revelaçấo de autores em seus diversos segmentos. (...) Que as vozes de nossos artistas da literatura, em registros da realidade ou criaçáo ficcional, reverberem e influenciem as geraçóes vindouras para novas conquistas e novos horizontes. (PUCCINELI, 2014. p. 7)

Neste projeto, portanto, săo listados e apresentados 18 nomes de escritoras mulheres, 3 delas em homenagens póstumas, entre 50 nomes no total. ${ }^{5}$ Ao passo que há um número nâo tâo inexpressivo de escritoras elencadas, ainda se evidencia a disparidade na representaçấo de nomes ilustres das letras entre homens e mulheres. Dentre os 9

$5 \quad$ Na época de publicaçăo, as escritoras eram Aglay Trindade Nantes (1934-1998), Flora Thomé (19302014), Nelly Martins (1923-2003). Maria da Glória Sá Rosa faleceu posteriormente, em 2016. 
escritores e escritoras já falecidos, as datas de nascimento variam entre 1906 e 1938 , e se consideramos que o estado de MS é ainda jovem, a vantagem do projeto Vozes da literatura é exatamente a possibilidade de homenagear a maioria dos autores e autoras ainda vivos e em plena produçăo intelectual e literária. Ademais, dentre estes percebemos uma variaçăo importante, pois ao longo do tempo houve maior abertura do espaço privilegiado de reconhecimento para incluir um maior número de escritoras na cena local, pois sấo 15 homenageadas. ${ }^{6}$

Outro fato a notar é que os nomes sâo citados em ordem alfabética, o que denota a intençăo de năo fazer uma hierarquizaçăo de qualquer espécie entre os autores e autoras, principalmente eliminando uma possível valoraçâo ou menosprezo da escrita feminina destas constantes na obra. Obviamente a questăo persiste nas entrelinhas do discurso do processo de seleçáo, entre a visibilidade quase 'natural' de escritores em detrimento de outros nomes de mulheres dedicadas à escrita, invisibilizadas quer pelos meios de legitimaçăo acadêmica, quer pela lógica mercadológica e editorial que porventura náo considere rentável investir em produçóes de mulheres ou que menospreze seu valor estético e literário.

A obra possui um caráter ampliado no que diz respeito às produçôes escritas para abarcar, dentro do estatuto do literário, tanto a ficçāo como outras formas de escrita sem o compromisso com a 'transcriçăo da realidade', se apropriando de linguagens e narrativas "pertinentes para comprovar ou rememorar fatos ocorridos, produzir saber histórico" (NOGUEIRA, 2014, p. 12) e assim compor o que o projeto da Fundaçáo de Cultura do Estado optou por incluir na literatura sul-mato-grossense. Como resultado,

[...] as vozes dos poetas, escritores, historiadores, memorialistas evidenciam a constante preocupaçáo com o redimensionamento da cultura, das artes, das tradiçôes, ao mesmo tempo em que reconhecem o compromisso que lhes cabe de fazer da literatura năo apenas um instrumento de lazer, mas, sobretudo, um veículo de conscientizaçâo social e de humanizaçăo (...) (NOGUEIRA, 2014, p. 15)

Nesta projeçấo quanto ao alcance da palavra escrita, literária, ainda cabe pensar o espaço que mulheres podem ocupar. Inclusive esta construçâo de memória, através da obra Vozes da literatura, parece ser erigida como forma de (re)conquistar o território intelectual, cultural, estético e literário, imprimindo a marca do feminino com mais ênfase. Como projeto coletivo, de proporçôes expandidas para a cena estadual, a organizaçăo é compartilhada equitativamente por uma assinatura masculina, de Fabio Pellegrini, e de uma mulher, Melly Sena; do mesmo modo, entre os autores dos textos de pesquisa biográfica e acerca das obras produzidas de cada um dos escritores e escritoras, há pelo menos 22 mulheres, o que denota uma maior inserçâo destas no campo da produçáo intelectual. Diante deste exemplo que acena para um caminho de maior abertura e menos díspar, certamente há muito a ser feito na descoberta do território da linguagem desbravado por outras mulheres que aliam sua produçâo escrita ao engajamento político de resistência.

6 As escritoras săo Ariadne Cantú, Blanche Torres, Delasnieve Daspet, Elizabeth Fonseca, Lélia Rita, Lori Gressler, Lucilene Machado, Maria da Rosa Sá Rosa, Maria Eugênia do Amaral, Marisa Bittar, Raquel Naveira, Sandra Andrade, Sylvia Cesco, Thereza Hilcar e Vera Tylde. 
Outras vozes ainda se percebem como balbucio, periféricas, fronteiriças, de mulheres indígenas ou migrantes, direta e indiretamente, em movimento e movimentando a poética e as narrativas do contemporâneo. Resta-nos, portanto, ampliar nossos horizontes de leitura para abarcar tais produçóes onde quer e como quer que se originem e se apresentem, e para isso uma nova postura crítica se faz necessária.

\section{PERSPECTIVA CONTEMPORÂNEA DA ESCRITA FEMININA: EXÍLIO E MOVIMENTOS MIGRATÓRIOS}

No âmbito da pesquisa em estudos de linguagens, cabe aos estudos literários e culturais contemporâneos colocar em foco produçōes locais e, com especial destaque, a produçáo de mulheres neste espaço fisicamente fronteiriço, tomando por base nossa própria geografia e espaço físico, mas expandindo a ideia para os campos metafórico e simbólico. Precisamos, portanto, desenvolver e ampliar a compreensâo crítica da produçăo artística regional, inscrevendo este estudo entre os demais que, nacional e internacionalmente, partem da crítica de(s)colonial e repensam as noçóes de produçâo de conhecimento a partir da desobediência epistêmica (Mignolo, 2014) e da reversáo da dívida e da influência (Santiago, 2019).

Olugar de nossa reflexāo é constituído pela referência geohistórica, biográfica, cultural e territorial do espaço de fronteira, com suas significaçôes simbólicas e inserçâo no espaço do saber latino-americano. A aparência geral do quadro tem sido alterada, e no horizonte surgem, com grande ênfase, rostos, corpos e măos femininos, povoando o espaço imaginário, acadêmico, social e cultural náo mais como objeto, talvez de contemplaçăo, passível de apreço ou menosprezo, mas como sujeito principal, ocupando o protagonismo de açăo e reflexăo, de produçăo artística e intelectual, adentrando o espaço antes fechado e negado. Além disso, pensar a partir do território fronteiriço inaugurado pelo necessário (re)posicionamento da escrita feminina nacional e regional deve agregar o traço da contemporaneidade mais imediata que exige teorizaçâo e propostas de abordagem, pois os deslocamentos humanos resultantes de exílios e migraçôes em massa devidos a várias causas possibilitam a produçâo estética de textos também migrantes, uma literatura em deslocamento que mimetiza a construçăo nômade do saber.

Do ponto de vista mais literal, observar tais movimentos, cuja significaçăo se ampliou em nossa história recente, significa perceber o protagonismo de mulheres que, encabeçando marchas e deslocamentos, ou mesmo se lançando nelas seguindo a outros, traçam um novo caminho para si e suas famílias, servindo como cuidadoras e elemento agregador, redesenhando as paisagens e estabelecendo outras formas de relaçóes nos locais por onde passam ou procuram se fixar.

O que trazem consigo, literal e simbolicamente? Quais marcas esses corpos físicos e metafóricos carregam e imprimem na nova paisagem cultural, ao manter formas de linguagem, preservar memórias e convertê-los em herança passível de repasse e modificaçōes, em meio a outras influências? Penso, aqui, nas măes, avós, tias, irmăs que preservam oralmente a história familiar, que nas açôes do cotidiano, de buscar sustento, alimento, roupa e abrigo, no mais básico papel de cuidar de si e dos outros, definem novos rumos para os relatos culturais de memória própria e alheia, coletiva. 
É neste sentido que habitar fronteiras constrói outras compreensōes e significados, nômades, inconclusos, migrantes e inquietos. Dar voz literária a elas significa permitir sua expressăo, sua escrita e sua leitura, convidando maiores públicos para o conhecimento e apreciaçăo. Entendemos, portanto, o espaço acadêmico como território para a busca e redescoberta de mulheres escritoras, antigas e atuais, como meio de amplificar o balbucio e o rascunho a proporçóes maiores e de acordo com o potencial feminino para a escrita, já existente, contudo borrado pelas tentativas de seu apagamento, como consideramos anteriormente, e alcançar outros leitores e ouvintes.

Apresentar as narrativas e construçōes de discursos locais é uma forma de dar visibilidade à produçấo do saber regional através da arte e da literatura, e fazê-los circular local e nacionalmente. Teoricamente, inclusive para nós, pesquisadoras e pesquisadores, se faz necessário o complemento do des-aprender para re-aprender proposto pela desobediência epistêmica (MIGNOLO, 2019), bem como a reflexăo proposta pela crítica de(s)colonial, como forma de prosseguir com o desenvolvimento de um olhar crítico e consciente essencial para os intelectuais, mulheres e homens, contemporâneos.

É neste respeito que ressaltamos a importância de desenvolver pesquisas locais para (re)pensar nosso próprio espaço de reflexáo e criaçâo literária, para voltar o olhar para o território simbólico no qual arte, saberes, narrativas, discursos e ficçóes surgem, ressurgem, săo ressignificados, migram e deslocam conceitos. Estes se tornam provisórios, diaspóricos e fundam o pensamento local com vistas ao universal, assim como projetos afins que elegem como opçâo de coexistência, de contraposiçăo ou de harmonia para promover o desprendimento do espelhamento da lógica que alia crescimento, consumismo a exploraçăo, marginalizaçăo e desvalorizaçăo humana, incluída a desvalorizaçâo da escrita de mulheres (Mignolo, 2014). Recorrer a textos de autoras locais e propor sua leitura e circulaçăo se enquadra bem na nova percepçăo social e política que a insistência na escrita traz consigo, tornando as letras o espaço de resistência para a inscriçâo de nomes e obras essenciais na memória da poética e das narrativas contemporâneas, no caráter humanizador, libertador e mais democrático da literatura.

Se a literatura produzida por mulheres surge em meio a formas de representaçăo e constroem visóes poéticas dos espaços físicos, metafóricos e simbólicos da linguagem, da expressáo e da percepçáo de pessoas e grupos, compondo o mosaico que revela tanto o regional como o universal, os projetos locais de escrita com traços indígenas, fronteiriços, pantaneiros, migrantes, exílicos, transnacionais, se expandem para as histórias globais (MIGNOLO, 2014), ultrapassando quaisquer barreiras e limites por seu caráter esteticamente humano, universal. Precisamos ler e dar a conhecer, por exemplo, autoras como Aglay Trindade Nantes e seu Morro Azul (1993) que, mesmo

sem se preocupar com a questăo de gênero e fazer uma história de mulheres, (...) destaca como linha condutora do seu livro a força da mulher pantaneira como o esteio familiar, tanto na fase da guerra como posteriormente, na difícil fase de reconstruçăo de propriedades e dos novos entrelaçamentos das famílias com casamentos e redistribuiçăo de terras. As mulheres foram, para as autoras, uma representaçăo simbólica de coragem, amor e resistência diante das adversidades. Elas deram a força necessária à sustentaçăo das histórias relatadas, aliás, histórias năo totalmente inventadas. (CORRÊA, 2014,p. 21) 
Das narrativas do espaço e da mulher da regiăo do pantanal, nos intrincados interstícios da memória e da criaçáo literária, surge uma prosa amena que revela o modo como os fios das histórias pessoais, familiares e locais se imbricam com a percepçâo do próprio território, a modo de uma compreensâo de si por meio da visăo geográfica, humanista e cultural.

Mas as demandas contemporâneas também ocupam espaço nas produçōes literárias locais que esperam por maior visibilidade. Delasnieve Daspet, autora de reconhecimento internacional, com obras traduzidas para línguas como inglês, francês, espanhol e alemáo, é também considerada uma biopoeta. Segundo Maria Helena Sarti, a escritora "defende a autodeterminaçâo dos povos e a preservaçăo do meio ambiente, enfim, usa as palavras que surgem para lutar contra as injustiças que sangram a quem respira" (2014, p. 120). Ademais, conhecida como "a poeta do Pantanal", nascida em Porto Murtinho, "é a voz de quem se perdeu, dos desvalidos, milita em prol das minorias" (SARTI, 2014, p.120). Trata-se, sem dúvida, de uma escritora de renome, inserida em 2011 no "Dicionário de Mulheres da historiadora Hilda Flores (Porto Alegre, RS)" (SARTI, 2014, p. 121), cuja obra năo tem aparecido na cena estadual como, acreditamos, deveria e poderia. Como escrita de mulher social, cultural e politicamente engajada, resta à academia contribuir para sua leitura e estudo.

Ademais, as implicaçōes da palavra poética com as memórias narradas, inventadas, reelaboradas, surgem na escrita de Gleycielly Nonato, escritora de origem indígena da etnia Guató que retoma a voz ancestral, da avó, da măe, das antepassadas mulheres em contos (publicados na coluna Ecoa, da Revista Ruído Manifesto), ou retomando histórias locais compreendidas como lorotas, causos ou histórias orais. Em Um conto de alma - Karáguejá I, por exemplo, lemos algo sobre a alma da ligaçăo familiar e as escolhas impostas pela cultura e pelas relaçôes, como um relato que se inscreve como escrita feminina:

Quando uma mulher dá à luz, seu corpo se quebra em milhares de pedaços. (...) Deuse a luz, mas nem tudo está claro.

Quando estava próximo do parto, as mais velhas me levaram para o rio. De cócoras, com as măos agarradas à galha de ingazeiro à beira da margem, fiz o canto virar grito. Tudo tăo assustador e bonito. Já deitada na rede, dando de mamá, fiquei imaginando como eu estaria agora se escolhesse devolver a criança às águas.

Quando uma mulher é abandonada pelo marido aqui na aldeia, a regra é clara: a mulher, se estiver grávida, tem o direito de escolher se devolve a criança, deixando o rio levar ao nascer, ou se vai assumir o filho sozinha. No primeiro caso, devolvendo a alma da criança ao rio, ela pode se casar de novo e constituir nova família. Se assume o filho, tem que partir sozinha para a mata e ser máe, caçadora, protetora... fera.

As mulheres da aldeia amparam a irmá, pelo menos até o período que a criança está amamentando. Trazem frutas, mel e caça. Para que ela fique forte e saudável para seguir sozinha. Todas estavam sentindo a mesma dor. A dor de ver a irmá com o filho nos braços, e um caminho incerto.

Dei à luz a uma menina. Uma forte menina de olhos de onça. (...) (NONATO, 2020)7

$7 \quad$ O texto foi reproduzido exatamente conforme a redaçấo do conto publicado em 18 de março de 2020. Disponível em ruidomanifesto.org, acesso em 01 de maio de 2020. 
Autora de dois livros, Índia do rio - poesias, de 2012, e Vila pequena - causos, contos e lorotas, de 2017, a jovem escritora produz textos que se alçam como uma voz polifônica da regiấo norte do estado de MS, nas intersecçóes entre o espaço geográfico, cultural e simbólico mimetizado em sua narrativa pessoal e familiar de vivência, experiência e ficçâo.

Como resultado, a escrita de mulheres se eleva frente aos - ou como os - monumentos que sâo, mais uma vez, erigidos; em foco, a configuraçăo contemporânea do real perpassada pela arte e estética, que fornecem uma forma de percepçăo e reflexâo importantes para a formaçăo humana do cidadâo do século XXI. Se os monumentos năo săo mais intocáveis e imutáveis, fixos, mas móveis e transitórios como retratos parciais e momentâneos, diaspóricos em sua constituiçăo atual e significaçăo, sua importância nâo foi reduzida; ao contrário, tornam-se mais e mais emblemáticos e sujeitos à reflexăo e interferência do leitor/espectador/observador. A fronteira emerge como espaço ficcional na literatura e na arte, mas, ponto de encontro, de ruptura ou de princípio e fim, sua descriçâo metafórica revela mais do que um território sobre o qual autores e autoras desenvolvem suas narrativas, ou onde personagens tecem seus discursos e as situaçôes possíveis săo representadas.

Ao analisar a literatura em sua relaçâo com o território fronteiriço e os estudos atuais da crítica de(s)colonial, năo se pode mais permitir a invisibilidade do feminino nos movimentos migratórios (TOMASCHESKI, 2010) ou em quaisquer outras circunstâncias e espaços. As narrativas locais, femininas, se inscrevem como objeto de leitura obrigatória.. Sấo a marca e a representaçâo do local impressas na contemporaneidade, e qualquer análise acadêmica e crítica que năo as leve em conta resultará parcial e incompleta.

\section{ALGUMAS CONSIDERAÇÕES PARCIAIS A MODO DE CONCLUSÃO}

A reflexăo acerca da escrita contemporânea brasileira e regional, feita por mulheres, demonstra que se trata de um espaço em construçăo, um territórios móvel que, ao longo do tempo, tem sido constituído como resistência e luta, uma postura artística, intelectual, cultural, social e política contra as imposiçôes e restriçôes que cerceiam a produçâo literária de autoria feminina. Apesar dos avanços, da ampliação dos processos de produçăo, divulgaçâo e do próprio número de mulheres dedicadas a esse ofício, nota-se que ainda subsiste um sistema de valoraçăo de obras que se ressente desta conquista, e isso implica um esforço maior para dar visibilidade a escritoras e obras.

Rastrear escritas femininas, quer como narrativas e leituras da fronteira, quer como processos de construçâo de literaturas migrantes e de exílio dos espaços simbólicos, metafóricos ou literais, no âmbito da pesquisa regional e nacional, coloca em perspectiva uma realidade local que pode - e deve - ser estudada em sua dimensăo global. Os encaminhamentos e as razóes da pesquisa acadêmica e sua difusáo em outros espaços, inclusive para públicos năo especializados e năo escolares, nos direcionam para uma nova compreensâo de como a produçâo literária, como produçâo artística, responde pelas novas conceituaçōes e formas de organizaçâo cultural e social a que assistimos nestas décadas iniciais do século XXI. Cabe-nos, como pesquisadoras e professoras, procurar formas de ampliar essa divulgaçăo e dar visibilidade às autoras e aos textos. 
Por um lado, uma nova episteme, ou pelo menos um novo posicionamento frente à (ou ao lado da) epistemologia retórica da modernidade, nas palavras de Mignolo, exigem uma postura intelectual que responda, satisfatoriamente, às novas formas de apresentaçăo dos discursos e narrativas pautados no entendimento das literaturas das minorias e de 'fronteira'. Estamos, certamente, diante de novas bordas, limites, espaços de começo e fim de pensamentos, de comportamentos, de construçóes identitárias, de simbologias, de modo que a organizaçâo do pensamento crítico já năo se vale das velhas fórmulas, e assistimos aos seus efeitos na nova configuraçăo dos espaços urbanos, nas relaçôes, no ser e estar no mundo, no próprio mundo. É nesta nova configuraçâo e postura intelectual que precisamos inserir a escrita de autoria feminina, bem como conduzir seu estudo acadêmico e sua divulgaçăo através do contato e ampliaçăo para outros públicos e leitores.

Do ponto de vista acadêmico, por em foco a escrita feminina significa utilizar um viés específico e profícuo para a observaçăo das convulsôes político-econômicas, ideológicas, os conflitos e relaçóes de poder, voltar os olhos para suas causas e seus efeitos, repensando a lógica da estruturaçăo das bases do que considerávamos uma sociedade estável pautada em uma visăo androcêntrica e patriarcal, e coloca-las em paralelo com um modelo de sociedade em transiçáo, em transmutaçáo, em processo dinâmico de mobilidade e avaliar suas instabilidades e processos e caminhos possíveis. O pensamento emergente torna-se coletivo, e revela a face de saberes e 'fazeres' que refletem tais convulsōes. Uma literatura considerada à margem surge como um objeto artístico cujos pressupostos éticos e estéticos dăo o sentido da ficçăo na atualidade por meio da escritura feminina que queremos promover para continuar a trazer à tona para essa e futuras discussōes. 


\section{REFERÊNCIAS}

ARAÚJO, Maria Conceiçăo Pinheiro. Lilithes, do século XX, abrem a caixa de Pandora das Sherazades, do século XIX. In: Revista Letras de Hoje, 2006. Disponível em: http:// revistaseletronicas.pucrs.br/ojs/index.php/fale/article/view/637/466

BATISTA, Carla. Autoras mulheres pioneira. In: FolhaPE.com. Coluna Mulheres em movimento, 01/05/2019. Disponível em: https://www.folhape.com.br/noticias/noticias/mulheres-em-movimento/2019/05/01/NWS,103651,70,1055,NOTICIAS,2190-AUTORASMULHERES-PIONEIRAS.aspx? fbclid=IwAR13ZY7VZI3ylDEjDCNxV8F-qjoJ2-DRAN8QapYLGd07C9YH2djBElYFZfc Acesso em 20/04/2020.

BENTO, Berenice. O lado feminino de Bolsonaro: os memes como sintoma. In: Revista Cult, 22 de abril de 2020. Disponível em: https://revistacult.uol.com.br/home/o-lado-feminino-de-bolsonaro-os-memes-como-sintoma/ Acesso em 30/04/2020.

BIBLIOTECA MARIO DE ANDRADE. Pioneiras: Exposiçăo. Secretaria de Cultura do Estado de Sáo Paulo. Disponível em: https://www.prefeitura.sp.gov.br/cidade/secretarias/cultura/bma/programacao/ index.php?p=25515 Acesso em 21/04/2020.

CRESTANI, Jaison Luís. Machado de Assis no Jornal das Famílias. Sáo Paulo: Edusp; Nankin Editora, 2009.

CORRÊA, Lúcia Salsa. Aglay Trindade Nunes. PELLEGRINI, Fabio; SENA, Melly. Vozes da literatura (orgs). Campo Grande: FCMS, 2014.

DUARTE. Constância Lima. Literatura de autoria feminina: uma história possível. In: ELÓI, Maria Amélia (curadora). As mensageiras: Primeiras escritoras do Brasil Exposiçăo. Série Histórias náo contadas 06. Brasília: Editora da Câmara dos Deputados, 2018.

LISPECTOR, Clarice. NUNES, Aparecida Maria (org). Correio para mulheres. Rio de Janeiro: Rocco, 2018.

LANSER, Susan S. The sexuality of History. Modernity and the Sapphic 1565-1830. Chicago: University Chicago Press, 2014.

FIGUEIREDO, Eurídice. Mulheres ao espelho: autobiografia, ficçăo, autoficçăo. Rio de Janeiro: EdUERJ, 2013.

MIGNOLO, Walter. Desobediencia epistémica. Retórica de la modernidade, lógica de la colonialidad y gramática de la descolonialidad. 2. Ed. Ciudad Autónoma de Buenos Aires: Del Signo, 2014.

MIGNOLO, Walter. El vuelco de la razón. Diferencia colonial y pensamento fronterizo. Ciudad Autónoma de Buenos Aires: Del Signo, 2019.

NANTES, Aglay Trindade. Morro azul - estórias pantaneiras. Campo Grande: Instituto Histórico e Geográfico de Mato Grosso do Sul, 2010.

NOGUEIRA, Albana Xavier. Vozes da literatura em Mato Grosso do Sul. In: PELLEGRINI, Fabio; SENA, Melly. Vozes da literatura (orgs). Campo Grande: FCMS, 2014. 
NONATO, Gleycielly. Um conto de alma - Karáguejá I. In: Revista Ruído Manifesto, conto de 18 de março de 2020. Disponível em ruidomanifesto.org, acesso em 01/05/2020.

NONATO, Gleycielly. Vila pequena: causos, contos e lorotas. Campo Grande: Fundo de Investimento do Estado de Mato Grosso do Sul, 2017.

PUCCINELLI, A. Formaçăo de leitores, difusăo de talentos, revelaçăo de autores. In: PELLEGRINI, Fabio; SENA, Melly. Vozes da literatura (orgs). Campo Grande: FCMS, 2014.

SARTI, Maria Helena. Delasnieve Daspet. In: PELLEGRINI, Fabio; SENA, Melly. Vozes da literatura (orgs). Campo Grande: FCMS, 2014.

SANTIAGO, Silviano. Uma literatura nos trópicos. Recife: Cepe, 2019.

TOMASCHESKI, Elisandra. Invisibilidade do feminino nos deslocamentos migratórios: relatos sobre a vida de dona Luzia. In: Revista Rascunhos Culturais. V. 1, n.1. Coxim, MS: A Universidade, 2010.

Recebido em06/05/2020

Aceito em 15/06/2020 